\title{
Prevention of skin reactions due to teletherapy in women with breast cancer: a comprehensive review
}

\author{
Marceila de Andrade ${ }^{1}$ \\ Maria José Clapis $^{2}$ \\ Talita Garcia do Nascimento ${ }^{1}$ \\ Thaís de Oliveira Gozzo ${ }^{3}$ \\ Ana Maria de Almeida²
}

One of the possible courses of cancer treatment is teletherapy, and one of the most important adverse side effects are skin reactions, an ailment more commonly called radiodermatitis. The main purpose of this study is to analyze knowledge of the evidence about topical products used in the prevention of radiodermatitis, to support care delivery to women with breast cancer during teletherapy. The research method used here is the comprehensive literature review. Four databases were used to select the bibliography. The sample consists of 15 articles. The data shows that, among the topical products analyzed here, Calendula, corticosteroids and Xclair have shown significant protective effects, underlining their actions. The lack of articles published in Brazil highlights the need for further research in this area, seeking better care quality through the use of products with scientifically proven efficiency.

Descriptors: Radiodermatitis; Radiotherapy; Breast Neoplasms.

\footnotetext{
${ }^{1}$ Master's students, Escola de Enfermagem de Ribeirão Preto, Universidade de São Paulo, WHO Collaborating Centre for Nursing Research Development, Brazil.

${ }^{2}$ Free lecturer, Associate Professor, Escola de Enfermagem de Ribeirão Preto, Universidade de São Paulo, WHO Collaborating Centre for Nursing Research Development, Brazil.

${ }^{3}$ PhD, Professor, Escola de Enfermagem de Ribeirão Preto, Universidade de São Paulo, WHO Collaborating Centre for Nursing Research Development, Brazil.
} 


\title{
Prevenção de reações de pele devido à teleterapia em mulheres com câncer de mama: revisão integrativa
}

Dentre as modalidades de tratamento para o câncer está a teleterapia, e um dos principais efeitos adversos dessa modalidade são as reações de pele, comumente chamadas radiodermatites. O presente estudo teve como objetivo analisar o conhecimento sobre as evidências acerca de produtos tópicos, utilizados na prevenção de radiodermatite, que fundamente o cuidado em teleterapia direcionado a mulheres com câncer de mama. Adotouse como método de pesquisa a revisão integrativa da literatura. Para a seleção da bibliografia utilizaram-se quatro bases de dados. A amostra constitui-se de 15 artigos. Os dados demonstram que, dentre os produtos tópicos analisados, a calêndula, os corticoesteroides e o Xclair tiveram efeito protetor significante, destacando-se, assim, pelas suas ações. A ausência de artigos publicados no Brasil mostra a necessidade de mais pesquisas nessa área, visando a melhor qualidade na assistência a mulheres com câncer de mama, por meio da utilização de produtos com eficácia comprovada cientificamente.

Descritores: Radiodermatite; Radioterapia; Neoplasias da Mama.

\section{Prevención de las reacciones en la piel debido a teleterapia en mujeres con cáncer de mama: revisión integradora}

\begin{abstract}
Teleterapia está entre las modalidades de tratamiento para el cáncer y uno de sus principales efectos adversos son reacciones de la piel, comúnmente llamado radiodermatitis. Este estudio objetivó analizar el conocimiento acerca de los productos tópicos utilizados para la prevención de la radiodermatitis que justifiquen la atención en teleterapia en mujeres con cáncer de mama. Se adoptó como método de investigación la revisión integradora de la literatura. Para la selección de los artículos se utilizaron cuatro bases de datos. La muestra fue constituida por 15 artículos. Los datos muestran que entre los productos tópicos analizados la caléndula, esteroides y Clair $X$ tuvo un efecto protector significativo, destacando así por sus acciones. La ausencia de artículos publicados en Brasil se centra en la necesidad de seguir investigando para mejorar la calidad de la atención mediante el uso de productos con una eficacia científicamente probada.
\end{abstract}

Descriptores: Radiodermatitis; Radioterapia; Neoplasias de la Mama.

\section{Introduction}

One of the treatment courses for breast cancer is teletherapy, which makes use of ionising radiation. This damages the cell components, with DNA as the main target. Radiotherapy brings about changes or even mutations to the genetic material, and also leads to changes in cell function, until the death of the cell. Thus, ionising radiation causes damage to all living and normal cells, as well as malignant ones, thereby causing side effects ${ }^{(1)}$.

Among local toxic effects, cutaneous reactions are highlighted, known as radiodermatitis: erythema, hyperpigmentation, dry scaling and moist scaling. What characterizes the latter is the exposure of the dermis and seepage of fluid, sometimes accompanied by exudate and crust or ulceration, or even necrosis(2-3).

The degree of skin reaction depends on several factors, such as: irradiation in places where there is contact between surfaces, areas where the epidermis is thin or where skin integrity has been ruptured, like in the case of burns, concurrent chemotherapy, immunotherapy, associated medical conditions or co-morbidity, chronic exposure to the sun, smoking, localization of the tumor or field treated, tumor staging, large irradiated volume, high dose of total radiation, dose with a fraction of more than $2.0 \mathrm{~Gy}$, and the type of energy used(2-3). 
In about $80 \%$ of the patients, radiation leads to dermatitis, varying in severity from moderate to severe erythema and moist scaling. The consequences are many, including decreased quality of life due to pain and interruption of treatment, which can be harmful for local control(4).

Several studies have been conducted to assess the results of preventive interventions, and the management of skin reactions caused by radiotherapy. There is a continuous lack of evidence to recommend many courses of intervention or products used in clinical practice though. Studies focus on prevention more than management, and are wanting in methodological rigor, making it difficult to repair studies with a view to elaborating specific recommendations. Other methodology problems include small sample size, wide variety in the terms used to describe reactions and measurement tools ${ }^{(3)}$.

Considering that radiodermatitis tends to occur quite often and harms the quality of life of radiotherapy patients, and also the lack of consensus about the topical products used in prevention, the main purpose of this study is to analyze knowledge on the topical products used in the prevention of radiodermatitis, with a view to supporting care delivery to women with breast cancer during teletherapy.

\section{Methodological Procedures}

For the development of this study, Evidence-Based Practice (EBP) was adopted as the theoretical and methodological framework. A comprehensive literature review was chosen. This method permits the analysis and synthesis of multiple published studies on a certain subject, as well as the identification of gaps that need to be filled through new research, and also general conclusions about a particular study area, with the resulting incorporation of the best and most recent evidence for decision making and improvement of clinical practice(5-6).

The preparation of the comprehensive review occurred in six stages: identification of the theme and selection of the hypothesis or research question, establishment of criteria for inclusion and exclusion of studies, sampling or search in the literature, definition of the information to be extracted from the selected studies, assessment of the studies included in the review, interpretation of the results and synthesis of knowledge ${ }^{(6)}$.

The guiding question for this review was: What scientific knowledge has been produced on topical products used in the prevention of radiodermatitis in women with breast cancer and subject to teletherapy?

For the selection of the bibliography, four different databases were used: MEDLINE (Medical Literature Analysis and Retrieval System Online), specifically
PubMed, LILACS (Latin American and Caribbean Centre on Health Sciences Information - Literatura LatinoAmericana e do Caribe em Ciências da Saúde), CINAHL (Cumulative Index to Nursing and Allied Health Literature) and the Web of Science, which is a set of databases (Science Citation Index, Social Science Citation Index, Arts and Humanities Citation Index, Current Chemical Reactions and Index Chemicus). Figure 1 displays the descriptors used in all the databases.

The criteria for inclusion as adopted to select the articles were: fully available; written in Portuguese, English or Spanish between January 2000 and July 2010;

\begin{tabular}{|l|l|l|}
\hline \multicolumn{1}{|c|}{ Database } & \multicolumn{1}{|c|}{$\begin{array}{c}\text { Controlled } \\
\text { Descriptors }\end{array}$} & \multicolumn{1}{|c|}{$\begin{array}{c}\text { Uncontrolled } \\
\text { Descriptors }\end{array}$} \\
\hline MEDLINE/ PUBMED & $\begin{array}{l}\text { Breast neoplasms } \\
\text { and therapeutics } \\
\text { and radiodermatitis }\end{array}$ & \\
\hline LILACS & $\begin{array}{l}\text { Radiodermatitis } \\
\text { Radiodermatitis and } \\
\text { breast neoplasms }\end{array}$ & \\
\hline CINAHL & $\begin{array}{l}\text { Radiodermatitis and } \\
\text { breast neoplasms }\end{array}$ & \\
\hline Web of Science & & $\begin{array}{l}\text { Radiodermatitis and } \\
\text { breast cancer or breast } \\
\text { neoplasms }\end{array}$ \\
\hline
\end{tabular}

Figure 1 - Descriptors used according to the database

a central theme based on topical products used in the prevention of radiodermatitis in women with breast cancer who have been subject to teletherapy.

A pre-selection was made, comprising 20 references in CINAHL, 16 in Web of Science, 97 in PubMed and 14 in LILACS. Through the reading of the title and abstract, we identified 15 articles that met the previously established inclusion criteria and addressed the guiding question, and were therefore part of the final sample.

In possession of the articles, each was exposed to exploratory reading. With a view to establishing categories and assess the studies, with the consequent interpretation of results, an instrument was used with the following items: identification, the institution where the study was conducted, the type of scientific publication, the methodological characterization of the study and the assessment of methodological rigor(7). Concepts nursing researchers proposed were used to set limits for the review ${ }^{(8)}$.

Concerning the identification of the selected papers' level of evidence, the following classification was used: level 1 - evidence from systematic review or meta-analysis of all relevant clinical trials, randomized and controlled, or arising from clinical guidelines based on systematic review of randomized controlled clinical trials; level 2 - evidence derived from at least one randomized well-defined clinical 
trial; level 3 - evidence obtained from well-defined clinical trials without randomization; level 5 - evidence arising from the systematic review of descriptive and qualitative studies; level 6 - evidence derived from one single descriptive or qualitative study; level 7 - evidence arising from opinions of authorities and/or reports from experts committees ${ }^{(9)}$.

Data were analyzed descriptively, permitting professionals to assess the quality of evidence about the research theme, thus supporting decision-making and the identification of knowledge gaps with a view to future research.

\section{Results}

The analysis of the 15 articles selected showed that, in five cases, the authors were nursing researchers, mostly in partnership with physicians from several different specialties. All were published in international journals and in English. I Research originated in several countries: the United States (3), Australia (2), India (2), Canada (1), France (1), Sweden (1), Germany (1), Israel (1), Spain (1) and Italy (1). In one case, the country of origin could not be established.

As for the studies' methods, thirteen articles had a quantitative approach, twelve being experimental studies (randomized controlled clinical trials) with evidence level 2 and one quasi-experimental study (Phase II clinical trial without randomization), with evidence level 3, considering strong evidence levels according to the classification used. One article was a narrative review of the literature and, as such, did not have an evidence level. The final article was a cohort study with evidence level 4 .

Figures 2, 3 and 4 present a summary of the articles analyzed.

\begin{tabular}{|c|c|c|c|}
\hline Study & Aim & Results & Conclusions \\
\hline $\begin{array}{l}\text { Schmuth et al. }{ }^{(10)} \\
\text { Randomized controlled } \\
\text { clinical trial }(n=36) \text {. }\end{array}$ & $\begin{array}{l}\text { To compare the efficiency } \\
\text { of Dexapantenol with } \\
\text { corticosteroids applied in } \\
\text { patients with breast cancer } \\
\text { and subject to radiotherapy } \\
\text { (RT). }\end{array}$ & $\begin{array}{l}\text { Comparisons of average severity scores between } \\
\text { groups as treated suggest that clinical progress } \\
\text { is less severe among patients who received } \\
\text { Methylprednisalone compared to those who } \\
\text { received Dexapantenol. The comparison between } \\
\text { the intervention and control groups suggests that } \\
\text { one of the two topical treatments produces better } \\
\text { results than no treatment, but the difference was } \\
\text { not statistically significant. }(p>0.05) \text {. }\end{array}$ & $\begin{array}{l}\text { The data suggests that topical } \\
\text { treatment is better than no treatment, } \\
\text { and corticosteroids seem to be more } \\
\text { effective than Dexapantenol alone. }\end{array}$ \\
\hline $\begin{array}{l}\text { Enomoto et al. }{ }^{(11)} \\
\text { Randomized controlled } \\
\text { clinical trial }(n=32)\end{array}$ & $\begin{array}{l}\text { Appraise the efficiency of Ray } \\
\text { Gel as a skin protector. }\end{array}$ & $\begin{array}{l}\text { The average severity score for skin reactions } \\
\text { was lower in the RayGel group (93.7) than in the } \\
\text { placebo group (123). }\end{array}$ & $\begin{array}{l}\text { Ray Gel showed a tendency to be } \\
\text { better than the placebo, but did not } \\
\text { achieve statistical significance due to } \\
\text { the sample size. }\end{array}$ \\
\hline $\begin{array}{l}\text { Shukla et al. }{ }^{(12)} \\
\text { Randomized controlled } \\
\text { clinical trial }(n=60)\end{array}$ & $\begin{array}{l}\text { Observe the difference in the } \\
\text { occurrence of moist scaling in } \\
\text { the underarm region with the } \\
\text { use of Beclometasone Spray. }\end{array}$ & $\begin{array}{l}\text { In the steroidal group, four patients }(13.33 \%) \text {, and } \\
11(36.66 \%) \text { in the control group, showed moist } \\
\text { scaling in the underarm region after a dose of } 50 \\
\text { Gy }(p=0.0369) \text {. }\end{array}$ & $\begin{array}{l}\text { The study shows a significant reduction } \\
\text { in the risk of moist scaling with the use } \\
\text { of topical steroids, and this should be } \\
\text { recommended for the start of RT with } \\
\text { maximum effect. }\end{array}$ \\
\hline $\begin{array}{l}\text { Fisher et al. }{ }^{(13)} \\
\text { Randomized controlled } \\
\text { clinical trial }(n=185)\end{array}$ & $\begin{array}{l}\text { Compare Biafine with the } \\
\text { best standard care for the } \\
\text { prevention of radiodermatitis. }\end{array}$ & $\begin{array}{l}\text { There was no difference in relation to maximum } \\
\text { toxicity, grade } 2 \text { toxicity or duration of radiodermatitis } \\
\text { between the patients treated with Aloe Vera, Biafine } \\
\text { and the standard care during RT. }\end{array}$ & $\begin{array}{l}\text { This study was unable to support the } \\
\text { hypothesis that Biafine is more effective } \\
\text { than standard care for the prevention of } \\
\text { radiodermatitis. }\end{array}$ \\
\hline $\begin{array}{l}\text { Graham et al. } .^{(14)} \\
\text { Randomized controlled } \\
\text { clinical trial }(n=61)\end{array}$ & $\begin{array}{l}\text { Test the prophylactic effect } \\
\text { of Cavilon } 3 \mathrm{M} \text { no-sting } \\
\text { barrier film on the rates of } \\
\text { moist scaling, compared with } \\
\text { Sorbolone cream (glycerine } \\
10 \%) .\end{array}$ & $\begin{array}{l}\text { No significant evidence was found in relation to } \\
\text { the values of pain or the need for analgesia. For } \\
\text { all patients, the average skin toxicity score was } \\
8.1 \text { in the case of No-Sting and } 9.2 \text { for Sorbolone, } \\
\text { respectively ( } p=0.005) \text {. The rate of moist scaling } \\
\text { was } 33 \% \text { in the case of No-Sting, compared with } \\
46 \% \text { (Sorbolone), with } p=0.096 \text {. }\end{array}$ & $\begin{array}{l}\text { The study suggests that the film is } \\
\text { better than Sorbolone, but it may not } \\
\text { be better than prophylactic skin care. } \\
\text { No-Sting film reduced the duration and } \\
\text { frequency of radiation-induced moist } \\
\text { scaling. }\end{array}$ \\
\hline $\begin{array}{l}\text { Pommier et al. }{ }^{(4)} \\
\text { Randomised controlled } \\
\text { clinical trial }(n=254) \text {. }\end{array}$ & $\begin{array}{l}\text { Assess the efficiency of } \\
\text { Calendula in the prevention } \\
\text { of Grade } 2 \text { radiodermatitis or } \\
\text { worse during RT for breast } \\
\text { cancer, when compared with } \\
\text { Trolamine. }\end{array}$ & $\begin{array}{l}\text { Incidence of acute skin toxicity of grades } 2 \\
\text { and } 3 \text { was } 41 \% \text { in the Calendula group and } \\
63 \% \text { for the Trolamine group ( } p=0.001) \text {. No } \\
\text { Grade } 4 \text { toxicity was observed. Adherence to } \\
\text { the application of the ointment was considered } \\
\text { satisfactory by } 84 \% \text { of the patients of the } \\
\text { Calendula group and } 92 \% \text { of the Trolamine } \\
\text { group. }\end{array}$ & $\begin{array}{l}\text { Calendula is highly effective in the } \\
\text { prevention of acute dermatitis of Grade } \\
2 \text { of higher, and shall be proposed } \\
\text { as preventive treatment for patients } \\
\text { subject to RT for breast cancer. }\end{array}$ \\
\hline $\begin{array}{l}\text { Roper et al. }{ }^{(15)} \\
\text { Randomised controlled } \\
\text { clinical trial }(n=20)\end{array}$ & $\begin{array}{l}\text { Assess the efficiency of Tetra- } \\
\text { Cream when compared with } \\
\text { Bepantol in the prevention of } \\
\text { radiodermatitis. }\end{array}$ & $\begin{array}{l}\text { There was no significant trend in favour of Bepantol } \\
\text { with a total average value of } 8 \text { compared to } 11 \text { for } \\
\text { Tetra-Cream }(p=0.17) \text {. There was no statistical } \\
\text { difference for the maximum value of each aspect } \\
\text { of skin toxicity for both groups at levels of } 30 \mathrm{~Gy} \\
\text { and } 50 \mathrm{~Gy} \text {. The patients have shown a high level } \\
\text { of satisfaction with the regime of care within both } \\
\text { groups. }\end{array}$ & $\begin{array}{l}\text { It was not possible to show any } \\
\text { advantages to the use of Tetra-Cream } \\
\text { compared with Bepantol in skin } \\
\text { care for patients subject to RT. The } \\
\text { physiopathology of radiodermatitis } \\
\text { needs to be studied to promote } \\
\text { therapeutic strategies. }\end{array}$ \\
\hline
\end{tabular}




\begin{tabular}{|c|c|c|c|}
\hline $\begin{array}{l}\text { Heggie et al. }{ }^{(16)} \\
\text { Randomised controlled } \\
\text { clinical trial }(n=225) .\end{array}$ & $\begin{array}{l}\text { Test the hypothesis that } \\
\text { topically applied Aloe Vera } \\
\text { was effective in reducing the } \\
\text { dermatological side effects } \\
\text { of RT when compared with } \\
\text { aqueous cream. }\end{array}$ & $\begin{array}{l}\text { The Kruskall-Wallis test was not significant for the } \\
\text { worst grades of seepage, pain and moist scaling } \\
\text { between the two groups. Regarding the worst } \\
\text { grade of dry scaling, it was statistically significant } \\
\text { for the Aloe Vera group having greater duration } \\
\text { and prevalence of such toxicity compared to } \\
\text { the Aqueous group ( } p=0.004) \text {. There was no } \\
\text { statistical difference between the groups in terms } \\
\text { of cumulative probability, prevalence and duration } \\
\text { of the erythema. }\end{array}$ & $\begin{array}{l}\text { Based on the study findings, Aqueous } \\
\text { Cream or a similar moisturizing agent } \\
\text { is recommended for use on the skin } \\
\text { during RT. Aloe Vera gel can be } \\
\text { beneficial when used together with } \\
\text { Aqueous Cream. }\end{array}$ \\
\hline $\begin{array}{l}\text { Bostrom et al. }{ }^{(17)} \\
\text { Randomised controlled } \\
\text { clinical trial }(n=50)\end{array}$ & $\begin{array}{l}\text { Establish whether } \\
\text { Mometasone Fuorate (a } \\
\text { corticosteroid), used in } \\
\text { prophylaxis and treatment, } \\
\text { can reduce the intensity } \\
\text { of the erythema in acute } \\
\text { radiodermatitis. }\end{array}$ & $\begin{array}{l}\text { The rate of total erythema in patients was } \\
\text { significantly lower in the Mometasone Fuorate } \\
\text { (MMF) group compared with the group treated } \\
\text { only with Emollient ( } p=0.0033 \text { ). The patients in } \\
\text { the MMF group have experienced less seepage } \\
\text { and burning than the Emollient group, but the } \\
\text { difference was not statistically significant. No } \\
\text { difference in relation to pain was found }(p=0.42) \text {. }\end{array}$ & $\begin{array}{l}\text { The results of this study support } \\
\text { the moderate use of corticosteroids } \\
\text { in topical form, from the first day of } \\
\text { radiotherapy through to } 3 \text { weeks } \\
\text { after the end of the treatment, } \\
\text { as a prophylactic agent against } \\
\text { radiodermatitis. }\end{array}$ \\
\hline $\begin{array}{l}\text { Omidvari et al. }{ }^{(18)} \\
\text { Randomised controlled } \\
\text { clinical trial }(n=68)\end{array}$ & $\begin{array}{l}\text { Assess the prophylactic effect } \\
\text { of } 0.1 \% \text { topical Betametasone } \\
\text { on radiodermatitis (ARD). }\end{array}$ & $\begin{array}{l}\text { End of } 3^{\text {rd }} \text { week: } 26.3 \% \text { of the Betametasone } \\
\text { Group developed Grade I dermatitis, compared } \\
\text { with } 64.7 \% \text { and } 66.7 \% \text { of the emollient group and } \\
\text { control group, respectively, with a statistically } \\
\text { significant difference ( } p=0.027) \text {. At the end of the } \\
7^{\text {th }} \text { week, } 15.8 \% \text { of the Betametasone group had } \\
\text { Grade } 1 \text { dermatitis, while the control group had } \\
6.7 \% \text { of such cases. Even though the patients } \\
\text { who received Betametasone had lower grades } \\
\text { of radiodermatitis than the other two groups, this } \\
\text { difference was not significant }(p=0.055) \text {. }\end{array}$ & $\begin{array}{l}\text { The study supports the prophylactic use } \\
\text { of Betametasone at } 0.1 \% \text { to prevent or } \\
\text { improve ARD. No effect of Petrolatum } \\
\text { (Vaseline) on the prevention of ARD } \\
\text { was found. }\end{array}$ \\
\hline $\begin{array}{l}\text { Szumacher et al. }{ }^{(19)} \\
\text { Non-randomised clinical } \\
\text { trial }(n=60) \text {. }\end{array}$ & $\begin{array}{l}\text { Assess the efficiency of Biafine } \\
\text { cream as a prophylactic agent } \\
\text { for radiation-induced acute } \\
\text { skin toxicity in women subject } \\
\text { to RT and chemotherapy for } \\
\text { breast cancer. }\end{array}$ & $\begin{array}{l}\text { During the RT: toxicity less than Grade } 2,15 \% \text {; } \\
\text { Grade } 2 \text { toxicity, } 83 \% \text {; Grade } 3 \text { toxicity, } 2 \% \text {; Grade } \\
4 \text { toxicity, no patients. For a period of four weeks } \\
\text { after RT, the highest skin reaction scores recorded } \\
\text { were: Grade } 0,15 \% \text {; Grade } 1,44 \% \text {; Grade } 2 \text {, } \\
34 \% \text {; Grade } 3,6 \% \text {. In the fourth week after RT, } \\
\text { the skin reaction scores for } 42 \text { patients with } \\
\text { available data were: } 83 \% \text { had a Grade less than } 2 \\
\text { and } 17 \% \text { had Grade } 2 \text { radiodermatitis. }\end{array}$ & $\begin{array}{l}\text { Most patients subject to QT and } \\
\text { simultaneous RT for breast cancer } \\
\text { developed Grade } 2 \text { radiodermatitis with } \\
\text { the use of Biafine cream. However, no } \\
\text { interruption or extension to the duration } \\
\text { of the treatment was observed as a } \\
\text { result of skin toxicity. }\end{array}$ \\
\hline $\begin{array}{l}\text { Fenig et al. }{ }^{(20)} \\
\text { Randomised controlled } \\
\text { clinical trial }(n=74) \text {. }\end{array}$ & $\begin{array}{l}\text { Assess the efficiency of Biafine } \\
\text { and Lipiderm in the prevention } \\
\text { of radiodermatitis. }\end{array}$ & $\begin{array}{l}\text { The analysis of the efficiency of the treatment did not } \\
\text { show any advantages when the three groups were } \\
\text { compared. However, } 19 \text { patients ( } 86 \% \text { ) in the Biafine } \\
\text { group and } 18 \% \text { ( } 85 \% \text { ) of the Lipiderm group showed } \\
\text { some degree of satisfaction with the treatment. }\end{array}$ & $\begin{array}{l}\text { No beneficial effects were shown for } \\
\text { either Biafine or Lipiderm, both widely } \\
\text { used in clinical practice to prevent } \\
\text { radiodermatitis. }\end{array}$ \\
\hline $\begin{array}{l}\text { Primavera et al. }{ }^{(21)} \\
\text { Randomised controlled } \\
\text { clinical trial }(n=20)\end{array}$ & $\begin{array}{l}\text { Assess the efficiency } \\
\text { of MAS065D (Xclair) in } \\
\text { radiodermatitis in patients } \\
\text { subject to radiotherapy for } \\
\text { breast cancer. }\end{array}$ & $\begin{array}{l}\text { Xclair showed significant benefits compared to the } \\
\text { product used in the control group, in relation to all } \\
\text { grades of skin reactions on the fifth visit and also } \\
\text { for erythema on the fifth and the seventh visits. } \\
\text { No significant difference was found in relation to } \\
\text { pain and seepage, comparing the two groups. In } \\
\text { relation to patient preference, } 65 \% \text { preferred Xclair, } \\
\text { while } 10 \% \text { prepared the control product. }\end{array}$ & $\begin{array}{l}\text { The results show a general reduction in } \\
\text { and delayed onset of radiodermatitis. } \\
\text { We can conclude that MAS065D } \\
\text { caused an ideal effect for the } \\
\text { management of skin reactions. }\end{array}$ \\
\hline
\end{tabular}

Figure 2 - Synthesis of research with experimental and quasi-experimental definition.

\begin{tabular}{|c|c|c|c|}
\hline Study & Aim & Results & Conclusions \\
\hline $\begin{array}{l}\text { Masferrer et al. }{ }^{(22)} \\
\text { Cohort Study }\end{array}$ & $\begin{array}{l}\text { Assess the efficiency of the } \\
\text { intensive use of a lotion } \\
\text { containing } 3 \% \text { urea, polydocanol } \\
\text { and hyaluronic acid to } \\
\text { prevent the onset of acute } \\
\text { radiodermatitis, and also control } \\
\text { its severity. }\end{array}$ & $\begin{array}{l}\text { Compared with the subgroup of controls that } \\
\text { had used the lotion under normal conditions, the } \\
\text { intensive use group had lower rates of occurrence } \\
\text { of radiodermatitis }(72.4 \% \text { VS } 100 \%, p<0.01) \text {, lower } \\
\text { toxicity }(p<0.001) \text { and also lower proportions of } \\
\text { radiodermatitis of Grade } 2 \text { or higher }(21.4 \% \text { vs. } \\
50 \%, p<0.01) \text {. The physicians and patients classify } \\
\text { efficiency, tolerability and cosmetic properties of the } \\
\text { lotion as good or excellent. }\end{array}$ & $\begin{array}{l}\text { The data show that the intensive use } \\
\text { of the lotion doubles the likelihood that } \\
\text { patients with breast cancer will not } \\
\text { develop radiodermatitis during RT, and } \\
\text { also halves the risk of developing toxicity } \\
\text { of Grade } 2 \text { or above. Both physicians and } \\
\text { patients associate it with good tolerability } \\
\text { and acceptance. }\end{array}$ \\
\hline
\end{tabular}

Figure 3 - Synthesis of research with non-experimental definition.

\begin{tabular}{|l|l|l|}
\hline \multicolumn{1}{|c|}{ Study } & \multicolumn{1}{c|}{ Aim } & \multicolumn{1}{c|}{ Synthesis } \\
\hline Aistars ${ }^{(2)}$ & $\begin{array}{l}\text { Analyze research on skin care during } \\
\text { radiation, specifically concerning } \\
\text { Narrative literature review . } \\
\text { erythema and dry scaling, between } \\
1996 \text { and June 2005. }\end{array}$ & $\begin{array}{l}\text { No difference was found between skin care products in the prevention of skin } \\
\text { toxicity in controlled and randomized clinical studies; the instrument known } \\
\text { as STAT (Skin Toxicity Assessment Tool) is valid and reliable as a measure of } \\
\text { radiation-induced skin toxicity. }\end{array}$ \\
\hline
\end{tabular}

Figure 4 - Synthesis of narrative literature review 


\section{Discussion}

Through an analysis of the selected publications, we identified a wide range of products used to prevent radiodermatitis in women with breast cancer during radiotherapy, such as covers based on topical corticosteroids, Biafine, Calendula, Tetra-Cream ${ }^{\circledR}$, Bepantol ${ }^{\circledR}$, Aloe Vera, and others.

Some studies show controversy about the efficiency of using topical corticosteroids in radiodermatitis treatment. In initial trials, the use of less potent corticosteroids, variations in the location and also the period to start the application, patients' heterogeneity in terms of cancer types, doses, regimens and application region of of radiotherapy and subjective analysis methods suggest that there is a lack of preventive effect for this substance. However, in the studies analyzed, we observed a clinical reduction in the severity of the symptoms shown, less damage to the skin permeability barrier and improvement of inflammatory response, resulting from the radiationinduced rupture of the barrier, as well as the significant reduction in the risk of developing moist scaling in patients using corticosteroids compared with those using other products $^{(10,12,17-18)}$.

According to the results shown, treatment with steroids should start together with the start of radiotherapy, for maximum effect. The importance of applications from the start of treatment is due to the fact that skin toxicity signs caused by radiotherapy may occur soon after the first dose of radiation ${ }^{(12,17)}$.

The protective effect of corticosteroids could be linked to their anti-inflammatory properties. Short-term observations have not shown any increase in the rate of telangiectasias, skin atrophy or the risk of suppression of the axis formed by the pituitary and adrenal glands. These factors limit their long-term use ${ }^{(18)}$.

Among the products analyzed, Betamesanone $0.1 \%$, Mometasone Fuorate and Beclometasone spray were the products that showed the best results and are also the most recommended for prophylactic use in the prevention of this co-morbidity.

However, the results of these research studies $(10,12,17)$ should be used with care, as some studies have methodology problems that could put the findings at risk, such as non-homogeneity and reduced sample size, loss of patients during follow-up, lack of blinding, lack of control of the main confounding factors and lack of a control group. New studies with greater methodological strictness are necessary to confirm these findings.

Another agent that has shown efficiency in the prevention of radiodermatitis during RT in women with breast cancer is Calendula. Through the results of the study, we have seen that this cover was statistically better in the prevention of Cutaneous toxicity of Grade 2 or higher. The clinical relevance of this result is stressed through the significant improvement in self-assessed pain-related patient satisfaction, low levels of allergies and treatment interruption, except for the facility of application, as the patients consider this difficult to apply ${ }^{(4)}$.

MAS065D (Xclair), which is a compound of hyaluronic acid, vitis vinifera, karité butter, telsmetine, glycyrrhizic acid and bisabolol in a hydrolipidic medium has also shown a protective effect in relation to skin toxicity due to radiotherapy. The main aim of this product is to reduce inflammatory reactions and keep a moist environment in the affected surface. Hyaluronic Acid (HA) is a natural biopolymer with a high capacity to retain water. It is the most important element of the extracellular unit of dermal tissue, providing mechanical and structural support. Clinical trials with the topical application of HA have shown improvement in wound cleaning, particularly in cases of radioepithelites, due to its notable rheological (viscosity), viscoelastic and hygroscopic properties (absorption of water), which are relevant in the healing process ${ }^{(21-22)}$.

Vitis vinifera and telmestine antiprotease have antioxidant properties that are able to inhibit harmful enzymes present in the exudate of the damaged skin and also protect the tissue from the damage free radicals cause. Another key substance that is present in Xclair is glycyrrhizic acid (liquorice root), which has antiinflammatory properties. In the case of karité butter, extracted from Parkii butyrospermum, it is used for its emollient action ${ }^{(21)}$.

The results of the study show a global reduction in skin reaction due to radiation, as well as a delay in its appearance. It could also be concluded that Xclair provides an efficient option for radiodermatitis management. Treatment efficiency concerning pain and seepage should be considered in further research, involving groups of patients with specific characteristics ${ }^{(21)}$.

\section{Final Comments}

According to the surveys analyzed, to prevent radiodermatitis due to $\mathrm{RT}$ in women with breast cancer, the most recommended products for topical use, according to the level of evidence and the methodological definition of the studies, are topical corticosteroids, Calendula and MAS065D (Xclair), which can therefore be incorporated into clinical practice.

The studies suggest, as an indication for the use of these products, uniform application, starting at the same time as the start of RT, twice a day or more often, 
depending on the occurrence of dermatitis and pain, until the treatment is completed or continuing for another two weeks after the end of treatment. In the case of Calendula, the restriction on use within 2 hours of the RT session should also be mentioned.

Radiodermatitis is an important side effect, due to its high rate of occurrence among patients submitted to teletherapy. It should be mentioned here that studies with a better methodological definition are needed to prove or reject these study findings. In addition, the lack of articles published in Brazil suggests the need for further research in this area, in order to establish protocol procedures for care related to prevention and appropriate management of the lesions, which institutions in search of better care quality can follow. The researchers hope that, through this study, interest on this subject in general will be enhanced.

\section{References}

1. Porock D, Kristjanson L. Skin reactions during radiotherapy for breast cancer: the use and impact of topical agents and dressings. Eur J Cancer Care. 1999;8(3):143-53.

2. Aistars J. The validity of skin care protocols followed by women with breast cancer receiving external radiation. Clin J Oncol Nurs. 2006;10(4):487-92.

3. McQuestion M. Evidence- based skin care management in radiation therapy. Semin Oncol Nurs. 2006;22(3): 163-73.

4. Pommier P, Gomez F, Sunyach MP, D'Hombres A, Carrie C, Montbarbon X. Phase III Randomized Trial of Calendula Officinalis Compared With Trolamine for the Prevention of Acute Dermatitis During Irradiation for Breast Cancer. J Clin Oncol. 2004;22(8):1447-53.

5. Lopes CMM, Galvão CM. Surgical Positioning: Evidence for nursing care. Rev. Latino-Am. Enfermagem. 2010;18(2):287-94.

6. Mendes KDS, Silveira RCCP, Galvão CM. Revisão integrativa: método de pesquisa para a incorporação de evidências na saúde e na enfermagem. Texto Contexto Enferm. 2008;17(4):758-64.

7. Ursi ES, Galvão CM. Prevenção de lesões de pele no perioperatório: revisão integrativa da literatura. Rev. Latino-Am. Enfermagem. 2006;14(1):124-31.

8. Polit DF, Beck CT, Hungler BP. Fundamentos de pesquisa em enfermagem: métodos, avaliação e utilização. $5^{\text {th }}$.ed. Porto Alegre: ArtMed; 2004. 487 p.

9. Melnyk BM, Fineout-Overholt E. Making the case for evidence-based practice. In: Melnyk BM, Fineout-Overholt E. Evidence-based practice in nursing \& healthcare: a guide to best practice. Philadelphia: Lippincott Williams \& Wilkins; 2005. p. 3-24.
10. Schmuth M, Wimmer MA, Hofer S, Sztankay A, Weinlich G, Linder DM, et al. Topical corticosteroid therapy for acute radiation dermatitis: a prospective, randomized, double- blind study. Br J Dermatol. 2002;146(6):983-91.

11. Enomoto TM, Johnson T, Peterson N, Homer L, Walts $\mathrm{D}$, Johnson N. Combination glutathione and anthocyanins as an alternative for skin care during external- beam radiation. Am J Surg. 2005;189(5):627-31.

12. Shukla P, Gairola M, Mohanti B, Rath G. Prophylactic beclomethasone spray to the skin during postoperative radiotherapy of carcinoma breast: a prospective randomized study. Indian J Cancer. 2006;43(4):180-4.

13. Fisher J, Scott C, Stevens R, Marconi B, Champion L, Freedman GM, et al. Randomized phase III study comparing best supportive care to Biafine as a prophylactic agent for radiation- induced skin toxicity for women undergoing breast irradiation: radiation therapy oncology group (RTOG) 97-13. Int J Radiat Oncol Biol Phys. 2000;48(5):1307-10.

14. Graham P, Browne L, Capp A, Fox C, Graham J, Hollis J, et al. Randomized, Paired Comparison of No- Sting Barrier Film Versus Sorbolene Cream (10\% Glycerine) Skin Care during Postmastectomy Irradiation. Int J Radiat Oncol Biol Phys. 2004;5(1):241-6.

15. Roper B, Kaising D, Auer F, Mergen E, Molls M. Theta- Cream versus Bephantol Lotion in Breast Cancer Patients under Radiotherapy. Strahlenther Onkol. 2004;180(5):315-22.

16. Heggie S, Bryant GP, Tripcony L, Keller J, Rose $P$, Glendenning $M$, et al. A Phase III Study on the Efficacy of Topical Aloe Vera Gel on Irradiated Breast Tissue. Cancer Nurs. 2002;25(6):442-51.

17. Bostrom A, Lindman $H$, Swartling C, Berne B, Bergh J. Potent corticosteroid cream (mometasone furoate) significantly reduces acute radiation dermatitis: results from a double- blind, randomized study. Radiat Oncol. 2001;59(3):257-65.

18. Omidvari $S$, Saboori $H$, Mohammadianpanah $M$, Mosalaei A, Ahmadloo N, Mosleh- Shirazi, et al. Topical betamethasone for prevention of radiation dermatitis. Indian J Dermatol Venereol Leprol. 2007;73(3):209.

19. Szumacher $E$, Wighton A, Franssen $E$, Chow $E$, Tsao M, Ackerman I, et al. Phase II study assessing the effectiveness of biafine cream as a prophylactic agent for radiation- induced acute skin toxicity to the breast in women undergoing radiotherapy with concomitant CMF chemotherapy. Int J Radiat Oncol Biol Phys. 2001;51(1):81-6.

20. Fenig E, Brenner B, Katz A, Sulkes J, Lapidot M, Schachter J, et al. Topical Biafine and Lipiderm for the prevention of radiation dermatitis: A randomized prospective trial. Oncol Rep. 2001;8(2):305-9. 
21. Primavera G, Carrera M, Berardesca E, Pinnaró $P$, Messina M, Arcangeli G. A Double- blind, vehicle- controlled clinical study to evaluate the efficacy of MAS065D (XClair), a hyaluronic acid- based formulation, in the management of radiation- induced dermatitis. Cutan Ocul Toxicol. 2006;25(3):165-71.

22. Masferrer J P, Mejía MM, Fernandéz MV, Astudillo AA, Armenteros MLH, Hérnandez VM, et al. Prophylaxis with a cream containing urea reduces the incidence and severity of radio-induced dermatitis. Clin Transl Oncol. $2010 ; 12(1): 43-8$. 